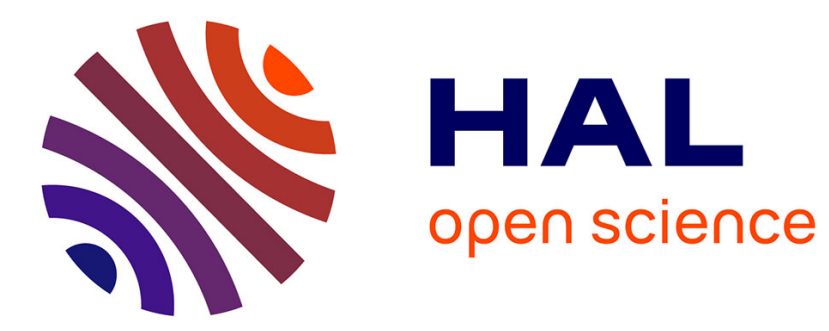

\title{
Hydromechanical properties of some mortars used in some ecologic construction techniques
}

Dashnor Hoxha, Ungureanu Vladimir Nicolae, Naïma Belayachi, Do Duc Phi

\section{To cite this version:}

Dashnor Hoxha, Ungureanu Vladimir Nicolae, Naïma Belayachi, Do Duc Phi. Hydromechanical properties of some mortars used in some ecologic construction techniques. Advanced Materials Research, 2012, 587, pp.6-10. hal-00746989

\section{HAL Id: hal-00746989 \\ https://hal.science/hal-00746989}

Submitted on 30 Oct 2012

HAL is a multi-disciplinary open access archive for the deposit and dissemination of scientific research documents, whether they are published or not. The documents may come from teaching and research institutions in France or abroad, or from public or private research centers.
L'archive ouverte pluridisciplinaire HAL, est destinée au dépôt et à la diffusion de documents scientifiques de niveau recherche, publiés ou non, émanant des établissements d'enseignement et de recherche français ou étrangers, des laboratoires publics ou privés. 


\title{
Hydromechanical properties of some mortars used in some ecologic construction techniques
}

\author{
Dashnor HOXHA ${ }^{1, \text { a }}$, Vladimir Nicolae UNGUREANU ${ }^{2, \mathrm{~b}}$, \\ Naima BELAYACHI ${ }^{1, c}$, Duc Phi DO ${ }^{1, d}$ and Jean-Baptiste THEVARD ${ }^{3, e}$ \\ ${ }^{1}$ Laboratoire Pluridisiplinaire de Recherche en Ingenierie de Systèmes, Mécanique et Energie \\ PRISME, Universite d'Orléans, 8 rue Léonard de Vinci, 45072 Orléans Cedex 2, FRANCE \\ ${ }^{2}$ Université Technique "Gheorghe Asachi", Bd. Dimitrie Mangeron 43, 700050 lasi, ROUMANIE \\ ${ }^{3}$ Association pour la PROmotion et la Construction d'Habitations Ecologiques en Paille, \\ APPROCHE-Paille, 11 rue de Lutèce - 45000 Orléans, FRANCE \\ adashnor.hoxha@univ-orleans.fr, bvlad.nicolae.ungureanu@gmail.com

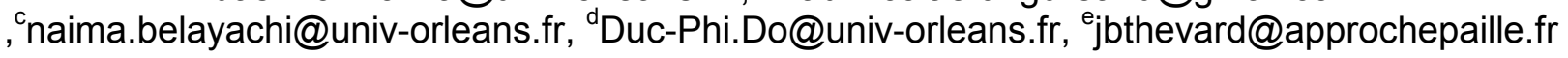

Keywords: Sawdust, mortar, GREB technique, straw bale construction, retention curve, water vapor permeability, uniaxial compression strength.

\begin{abstract}
This paper presents results of hydromechanical characterization tests performed on some mortars used in eco-construction practice. Typically, such mortars could be found in buildings constructed following so called GREB technique that uses straw bales as structural and insulating elements in addition to a wood frame. The full experimental program includes thermal, mechanical and hydraulic - hygroscopic tests. Mechanical tests, including uniaxial compression test and three point bending test and hydraulic tests including water and vapor water permeability, retention curve and unsaturated water permeability have been performed on three earth-cement mortars with sawdust additive. Tests were performed in age of 7, 14, 28 and 120 days. For retention curve and so called relative permeability a simple method has been used based on measurements of masse variations of samples on a controlled humidity environment and an inverse problem approach. Using of sawdust improves hydraulic properties of these mortars but the early age strength of these mortars has to be improved by cement additives.
\end{abstract}

\section{Introduction}

In relation with the global efforts to minimize the anthropologic impact on the nature, the eco-constructing nowadays has become a major issue in constructing practice [1]. More and more, in artisanal and industrial practices the objectives in terms of overall impact are formulated nnot only on final thermal efficiency of buildings but also in so-called gray energy used in materials used for constructions. This justifies the increasing interest on straw bale based constructions, initially used for their low economic cost in rural regions $[1,2,3,4]$.

The GREB technique $[2,5]$ initially developed by Ecologic Research Group of Baie (Groupe de $R$ echerches Ecologiques de la Baie, GREB, Canada) uses a wood frame as principal structural element and adds straw bales along with well positioned staples and metallic meshes in order to obtain a solid structure and an efficient insulating envelope. The finishes of such constructions are usually made by clay plasters with addition of sawdust or alternatively by earth cemented mortars enriched by various fibers such as chopped straw, hemp fiber, nylon fiber, and animal hair. The objective of finishes is to provide mechanical and fire protection of the bales, to restrict the passage of air through the bales, and to protect them from weather. While various studies on mechanical and thermal properties of straw bale walls $[3,4,6]$ confirm the suitability of such construction techniques for low ecologic impact buildings, the main concerns about them is the durability, hydrous state and moisture permeability in order to avoid fungus formation $[6,7]$. 
In this paper various formulations of finishes mortars used in GREB techniques are tested mechanically and hydraulically in order to obtain their characteristics in terms of mechanic and hydraulic resistance. These characteristics could be used on numerical simulations in order to assess the hydrous state of straw bale walls in given regional climatic conditions and to evaluate the risks of fungus apparition if any. Only experimental program of mechanical and hydraulic characterization of mortars is presented here. After a short description of materials studied in this work, laboratory techniques are presented briefly followed by results and a short discussion.

\section{Description of materials}

Three mortars that differ to each other from rapport of cement used in their formulas are used in this study. Firstly, a traditional mortar used in GREB construction is studied (referenced hereafter as F0 formulation): it is constituted by 4 sawdust parts (in volume), 3 parts of sand, 1 part of lime and 1 part of Ordinary Portland Cement (OPC). This standard traditional formulation is compared with two other formulas in which the contribution of OPS is initially reduced at 50\% (F1 formulation) and finally has completely dropped from formulas (F2 formulation). The samples for F0 formulation have been prepared directly in a building site, while for two others formulations samples were prepared in laboratory. In order to keep as much as possible a homogeneous material from one sample to another one, for each formulation the samples were prepared from a single mixing apparatus. Each sample obtained an identification number and then introduced in the testing schedule. All samples were kept in atmospheric conditions of laboratory during all the period preceding testing.

\section{Laboratory setups and test conditions}

Mechanical tests were performed using a classical procedure and devices at different ages of samples: 7, 14, 28 and 120 days, respectively, following European standards (EN 196-1). The axial load is applied by a servo-controlled actuator and the normal displacements are measured by a LVDT sensor. For the three points bending tests, prismatic square-bases samples with standard dimensions (40 $\mathrm{mm} \mathrm{x}$ $40 \mathrm{~mm} \times 100 \mathrm{~mm}$ ) were used and the same loading device is used as for compression tests. It is then possible, knowing applied force (when the macroscopic failure of samples is observed), to calculate tensile stress at failure known as bending strength.

The water permeability tests are performed on saturated cylindrical tests using a classical cell and standard steady conditions: maintaining a pressure difference between two bases of cylindrical sample one measures the water flow out and then calculates water permeability using Darcy's law. Knowing temperature of test and water viscosity it is then possible to access to the intrinsic permeability of tested sample.

For the vegetal-fibered walls, most often is more important to characterize the liquid water transfer and condensing capacity of a wall then water vapor permeability, which of course is always interesting to know. As mentioned by many authors, obtaining the full retention curve and water permeability in unsaturated conditions is a time-consuming process. In order to accelerate it, in this work a method suggested in [9] has been used. Following this method, instead of steady state measurements commonly used in practice, we use transient response of materials in terms of masse variation of samples and identify the permeability with the helps of a numerical inverse problem approach. Practically wise, we measure the mass taking (losing) of a sample when it is put in an atmosphere of controlled relative humidity $(\mathrm{RH})$. The relative humidity is maintained during a test by the help of salt solutions technique: one puts a sample in a closed, isothermal cell communicating with a reservoir of an oversaturated salt. The salt solution through exchanges with the closed atmosphere of the cell and sample creates a constant relative humidity in the cell. Measuring the mass taking (losing) of as sample as a function of time allows in one hand identifying the relative permeability (see [9]) and in the other hand constructing of retention curve. The salt solutions used in this study and their equilibrium relative humidity are given in table 1 . In our tests, in order to create appropriate conditions for interpretation, thin cylindrical samples, with know base surface were 
isolated on laterals, so that the hygroscopic exchanges with the cell atmosphere are possible only through the bases of the sample and the problem of water transfer becomes $1 \mathrm{D}$, which considerably simplifies the inverse problem. The theoretical bases of inverse problem and relative permeability identification are not detailed here (the interested reader could find details in [9] and references cited therein)

Table 1: Salt solutions used in study and their equilibrium relative humidity

\begin{tabular}{|c|l|l|}
\hline $\begin{array}{c}\text { Level } \\
\text { test }\end{array}$ & Salt Solution & $\begin{array}{l}\text { Relative Humidity at } \\
\text { equilibrium [\%] }\end{array}$ \\
\hline 1 & $\mathrm{MgCl}_{2}$ & $33.07 \%+/-0.18 \%$ \\
\hline 2 & $\mathrm{Mg}\left(\mathrm{NO}_{3}\right)_{2}$ & $54.38 \%+/-0.23 \%$ \\
\hline 3 & $\mathrm{NaCl}$ & $75.47 \%+/-0.14 \%$ \\
\hline 4 & $\mathrm{KCl}$ & $85.11 \%+/-0.29 \%$ \\
\hline 5 & $\mathrm{KNO}_{3}$ & $94.62 \%+/-0.66 \%$ \\
\hline 6 & $\mathrm{~K}_{2} \mathrm{SO}_{4}$ & $97.59 \%+/-0.53 \%$ \\
\hline
\end{tabular}

\section{Principal results}

Mechanical tests. Typical failure patterns of samples after uniaxial compression tests are given in the Fig. 1.a, while three point bending device is shown in the Fig. 1.b. As a general rule the failure of sample is of ductile type whatever cement content is. As expected, the strength of samples, deduced by uniaxial compression tests, increases with the age of samples and with fraction OPC used $\mathrm{t}$. However as shown in Fig. 2, the differences are far more important between F0 (reference) and F1 (cement content reduced by $50 \%$ as compared to F0), than between F1 and F2 (no cement at all).
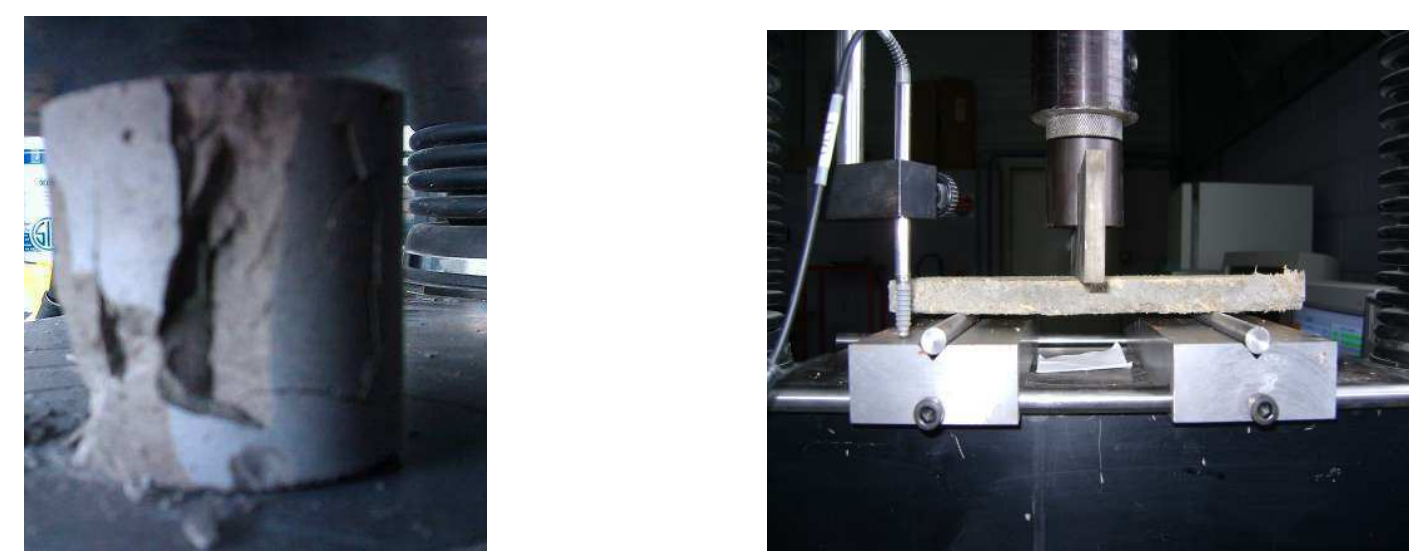

Figure 1: Pattern failure of samples under uniaxial compression and three points bending tests device

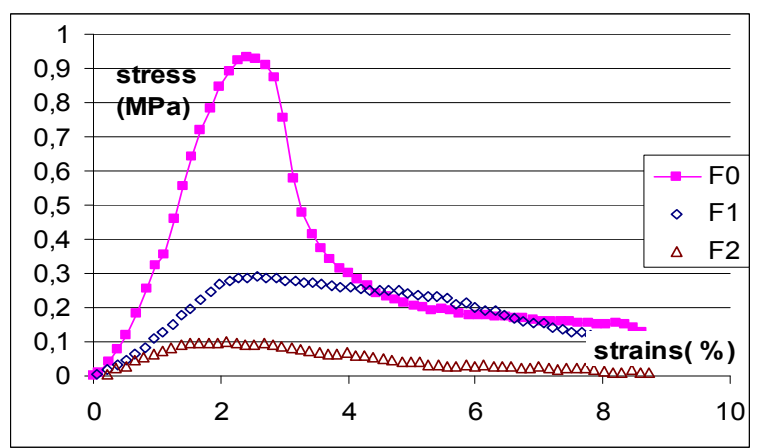

Figure 2.a : Stress-strains curves form uniaxial compressions tests ( $\mathrm{t}=120$ days)

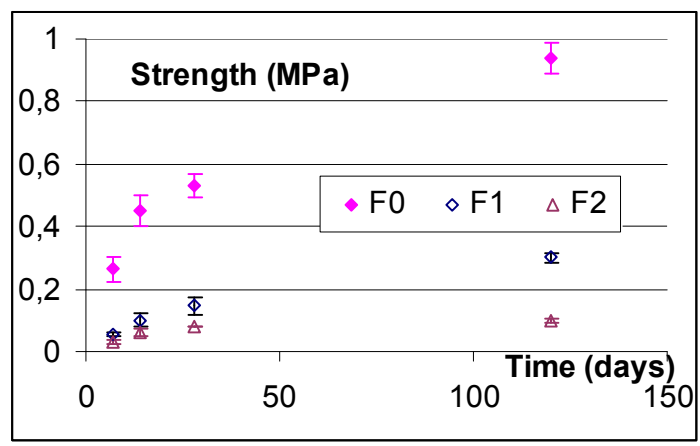

Figure 2.b : Evolution of compression strength with the age of samples 
In the Fig. 3.a is shown a typical result from three points bending tests, while in figure 3.b is presented the evolution of bending strength as a function of the age of tasted samples. Again, no substantial differences are observed in behavior of F1 and F2 samples, while F0 samples clearly demonstrates a better mechanical resistance, especially in bending.

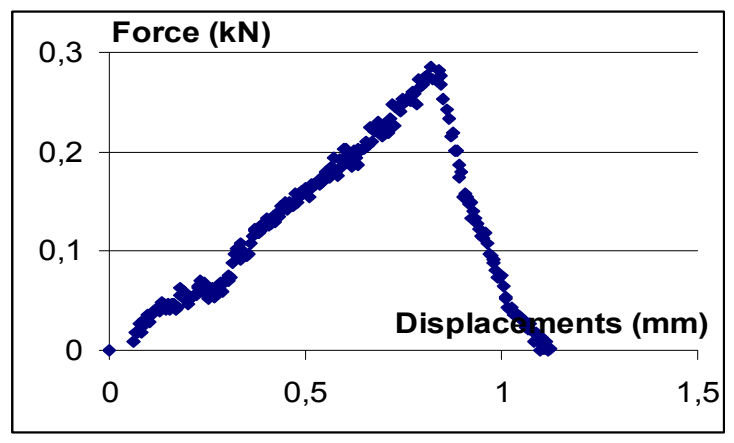

Figure 3.a Example force displacement curve from three points bending test

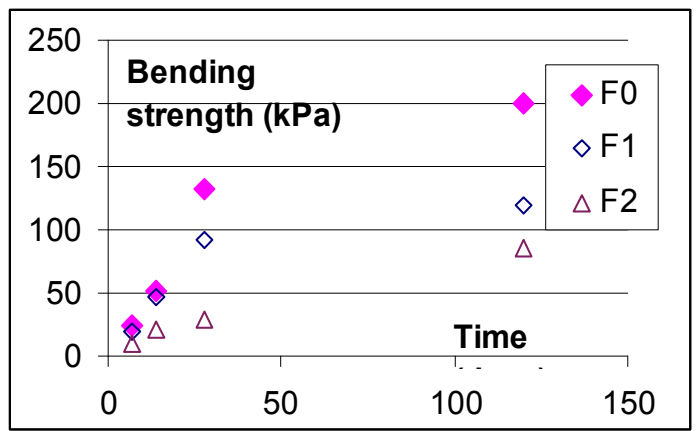

Figure 3.b : Evolution of bending strength with the age of samples

Hydraulic and hygroscopic tests. There were technical difficulties in measuring water-saturated permeability of all samples. These difficulties were due to the swelling of samples once saturated and some forms of decohesion of sawdust when fully saturated in water. So, all necessary precautions have to be taken in the interpretation of obtained values. Following these results water-saturated permeability decreases when the cement content increases going from $2.210^{-15} \mathrm{~m}^{2}$ for reference samples to $5.410^{-15} \mathrm{~m}^{2}$ for $\mathrm{F} 1$ samples and $1.210^{-14} \mathrm{~m}^{2}$ for $\mathrm{F} 2$ samples.

Typical results of masse evolution of samples as a function of time are presented in the Fig. 4.a. As already mentioned a test of mass taking (loosing) is performed for each salt-solution-regulated relative humidity, so that a set of 18 graphics similar to that shown in Fig. 4.a is obtained and treated. Taking into account the measured porosity of each sample and numerical procedure indicated in [9], values of unsaturated permeability are calculated for each sample and results are presented in Tab 2.

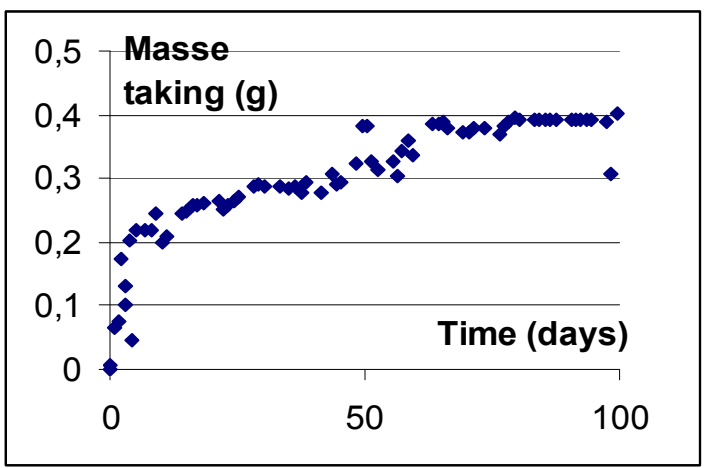

Figure 4.a : Masse evolution of sample \#5F0 during hygroscopic equilibration (level 4 to 5)

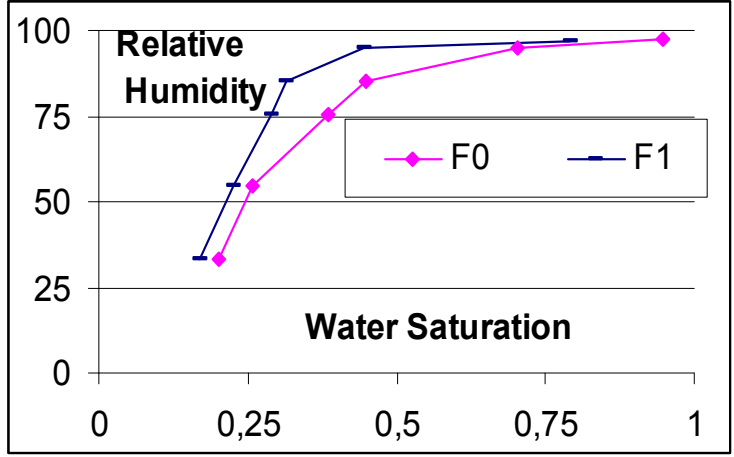

Figure 4.b : Retention curve from masse variation tests for two of mortars

Table 2 : Unsaturated effective water permeability deduced from mass variation tests

\begin{tabular}{|c|c|c|c|c|}
\hline \multicolumn{2}{|c|}{ Masse variation curve used in } & \multicolumn{3}{|c|}{ Permeability of samples from [m $\left.{ }^{2}\right]$} \\
\cline { 3 - 5 } identification of water permeability & Mortar F0 & Mortar F1 & Mortar F2 \\
\hline From $\mathrm{RH}=33 \%$ & To $\mathrm{RH}=54 \%$ & $3.5610^{-18}$ & $4.5310^{-18}$ & $0.1110^{-17}$ \\
\hline From $\mathrm{RH}=54 \%$ & To $\mathrm{RH}=76 \%$ & $1.1410^{-17}$ & $1.4410^{-17}$ & $1.3610^{-17}$ \\
\hline From $\mathrm{RH}=76 \%$ & To $\mathrm{RH}=85 \%$ & $7.8310^{-17}$ & $1.6610^{-16}$ & $7.4210^{-17}$ \\
\hline From $\mathrm{RH}=85 \%$ & To $\mathrm{RH}=95 \%$ & $1.4510^{-16}$ & $1.2710^{-16}$ & $1.6810^{-16}$ \\
\hline From $\mathrm{RH}=95 \%$ & To $\mathrm{RH}=97 \%$ & $0.7110^{-15}$ & $0.4210^{-15}$ & $0.5210^{-15}$ \\
\hline
\end{tabular}


Considering the mass of samples at equilibrium for a given $\mathrm{Hr}$ it is possible to finally construct the retention curve of each formulation (Fig. 4.b)

\section{Discussion and concluding remarks}

While the presence of cement in mortar formulation seems quite useful to give them the necessary strength, especially in the very first days, even if the cement maintains a high capillary capacity and significant water liquid permeability. The compromise found empirically in the practice of GREB construction to use cement at about $10 \%$ of inert constituents seems to be quite close to the optimum. In fact for smaller percentages of cement the mechanical properties decreases drastically. It particular the presence of the cement seems to influence the relative permeability for law capillary pressure, close to full saturated state. As discussed by several authors the problem of humidity in the buildings is above all a problem of capillary liquid water transfer. From this point of view it seems that F0 (reference mortar) is the worst protector among studied mortar. As shown in Tab. 2 liquid water permeability for reference formulation (with maximum cement) is smaller for the smaller capillary pressure which implies that it has the higher resistance to water vapor, but it is this mortar that could transfer by capillarity more humidity when slight unsaturated. Shifting towards a mortar with less cement would not only be more ecologic (since less cement means less grey energy) but also would be more appropriate for moisture transfer. For that, the problem of mechanical stability of mortar should be resolved beforehand and recent ongoing researches aims at obtaining an optimized mortar from thermal, hydraulic and mechanical properties point of view.

\section{References}

[1] J.C. Morel, A. Mesbah, M. Oggero, P. Walker, Building houses with local materials: means to drastically reduce the environmental impact of construction. Building and environment, Volume 36, Issue 12, Pages 1119-1126, (2001)

[2] V. BROSSAMAIN, J.B THÉVARD, Construire sa maison en paille selon la technique du GREB (2006)

[3] U.S. Department of Energy, Energy Efficiency and Renewable Energy, April 1995, www.eere.energy.gov/buildings/info/components/envelope/framing/strawbale.html

[4] The Federal Ministry of Traffic, Innovation and Technology (Department for Energy and Environmental Technologies) and the Austrian Energy Agency, Wall systems made of renewable resources: Testing and optimising post and beam straw bale constructions, http://energytech.at/architektur/publikationen/results/id1777.html.

[5] C. de la ROSA, Contribution aux mesures mécaniques sur la construction paille selon la technique du GREB Master Dissertation (in French) (2008),

[6] Steve Goodhew, Richard Griffiths, Tom Woolley, An investigation of the moisture content in the walls of a straw-bale building, Building and environment, Volume 39, Issue 12, Pages 1443-1451 (2004)

[7] Jim Carfrae, Pieter De Wilde, John Littlewood, Steve Goodhew, Peter Walker Development of a cost effective probe for the long term monitoring of straw bale buildings, Building and Environment, Volume 46, Issue 1, January 2011, Pages 156-164

[8] V. Ungureanu Characterization of mortars used in GREB technique, Master Dissertation of University of Orleans, July 2010

[9] Homand F., Giraud A., Escoffier S., Koriche A. \& Hoxha D. - Permeability determination of a deep argillite in saturated and partially saturated conditions - International Journal of Heat and Mass Transfer. Volume 47, Issues 14-16, pp. 3517-3531 (2004) 